\title{
RESPONSE OF, RHOPALOSIPHUM PADI L. TO SOME BIOTIC, ABIOTIC FACTORS AND PHYTOCHEMICAL COMPONENTS OF FIVE WHEAT VARIETIES
}

\author{
EL-MITWALLY, M. F. ${ }^{1}$, F. F. SHALABY ${ }^{2}$, \\ M. M. ASSAR ${ }^{2}$ and A. M. KHORCHID ${ }^{1}$ \\ 1. Plant Protection Research Institute, ARC, Dokki, Giza, Egypt. \\ 2. Plant Protection Department, Faculty of Agriculture, Moshtohor, Benha \\ University, Egypt.
}

(Manuscript received 2 May 2013)

\begin{abstract}
The infestation levels of bird cherry-oat aphid, Rhopalosiphum padi L. wer been studied on five wheat (Triticum aestivum) varieties viz., Giza 168, Sides 1, Gemmeiza 7, Gemmeiza 9 and Sakha 93 throughout 2005\06 and 2006\07 growing seasons at the Agricultural Research Institute, Ismailia governorate, Egypt. Recorded relative population densities of $R$. padi were correlated with some abiotic (temperature and relative humidity) and biotic (predators \& Parasitoids) factors during both seasons. Sids 1 variety showed highest susceptibility, while Sakha 93 variety was the least susceptible one. Results showed significant differences between the five wheat varieties for $R$. padi population abundance (adults and nymphs) in both seasons. Presence and rates of phytochemical components in leaves of the different wheat varieties were studied.
\end{abstract}

Key words: Rhopalosiphum padi, Infestation, wheat varieties, Parasitoid, predator, Susceptibility, Weather factors.

\section{INTRODUCTION}

Wheat (Triticum aestivum L.) is the most important strategic cereal crop in Egypt. More than 2.538 million feddans are cultivated in old land, in addition to 526 thousand feddans in new lands. Many pests attack the wheat plants leading to great loss in quality and quantity of the yield. In Egypt, The population needs cereals foods in our consummation over the production of the wheat crop more than $60 \%$.

The bird cherry-oat aphid, Rhopalosiphum padi L, may be considered as one of the major insect pests attacking wheat crop in Egypt as in years of outbreak of this aphid, it causes severe damage to plants resulting from direct sap-drainage by aphids feeding. The quick build up of aphids populations is attributed to quick reproduction by parthenogenesis, moderate weather conditions and continuous existence of cereal (geramineous) crops all the year round, (Tantawi et al., 1986). Some commercial bread wheats were screened for resistance against the main cereal aphid species (Ruchira et al., 2002). Sekhar and Singh (1999). They reported that the plants are mainly infested with the Indian grain aphid, Macrosiphum miscanthi and the bird 
cherry oat aphid, R. padi in India. R. padi infested all above ground plant parts, but was more preponderant on leaves and stem (foliage). Dry matter analysis revealed the presence of free amino acids and sugars in leaves and spikes of varieties (Havlickova, 1996).

Webster and Porter (2000) evaluated the impact of resistance to wheat aphid, Diuraphis noxia, Metopolophium dirhodum, Sitobion avenae, and $R$. padi. on some wheats. Abou-Elhagag et al. (2001) evaluated the susceptibility of ten wheat varieties to three cereal aphid species ( $R$. padi, Schizaphis graminum and $R$. maidis) in Egypt. Akhtar et al. (2007) evaluated eleven wheat lines against Rhopalosiphum padi. The author stated that three lines were resistant, while the varieties namely Chakwal-97 and V-002467 were susceptible to aphid attack whereas seven lines were moderately resistant. In seedling bulk tests, Akhtar et al. (2008) evaluated twenty wheat varieties against Rhopalosiphum padi in Pakistan. These varieties were grouped into three categories (i.e resistant, moderately resistant and susceptible). In which, data from seedling bulk tests showed that DN-47 and PR 87 lines of wheat were resistant to aphid as compared to the other varieties. The present experiment was carried out to study out the population abundance of $R$. padi in relation to biotic and abiotic factors and also, to different wheat varieties.

\section{MATERIALS AND METHODS}

For studying impact of some biotic and abiotic factors on population of $R$. padi on different varieties of wheat two successive experiments were conducted at the experimental farm of Ismailia Agricultural Research Station during two 2005/ 2006 and 2006 / 2007growing reasons. Five varieties of wheat viz., Giza 168, Sides 1, Gemmeiza 7, Gemmeiza 9 and Sakha 93 were sown on November $15^{\text {th }}$ of each year. The experiments were laid out in a randomized complete block design with four replications and plot size was kept at $105 \mathrm{~m}^{2}$. Cultural methods were followed as commonly practices and chemical control was entirely avoided during the growing seasons. For estimating the population density of cereal aphids and their natural enemies, samples of 40 tillers per replicate were randomly collected at weekly intervals starting from the beginning of December 2005 to crop harvesting on 1 April 2006. The tillers were refrigerated until examined within $24 \mathrm{hr}$. All aphids including mummies (parasite) and predaceous insects per tiller were counted with the aid of binocular microscope. Aphid mummies were placed individually is small plastic tubs and held for parasite emergence. The parasites were identified by specialists at Plant Protection Institute. The recorded counts of beneficial natural enemies were statistically correlated with aphids infestation. The relationship between certain abiotic 
factors and the population dynamics of this pest during the two successive seasons 2005\06 and 2006\07 were studied. Daily maximum and minimum temperature and relative humidity were recorded from data of the Central Laboratory of Agricultural Climate, Agricultural Research Centre, Dokki, Giza.

The number of individuals was accumulated for seven days for the whole data of the two seasons in relation to the abiotic and biotic factors.

The relationship between the leaf phytochemical components and infestation levels by $R$. padi was studied on the five wheat varieties through the two growth stages (seedlings and heading stages) during 2005/06-2005/07 seasons. Leaves of each sample were cleaned and washed by water, then quickly dried by placing between two filter papers to remove the excess of water. The fresh weight of leaves was recorded. The leaves were placed in drying oven at $45{ }^{\circ} \mathrm{C}$ for one day. The dry powder of leaves was stored in glass bottles to determine carbohydrates and total protein contents according to the methods of Pregl (1945) and Michel et al. (1956). The percentages of the reduced, non-reduced and total sugars were also estimated in the dry powder using the method of Forsee (1938). The phosphorous content was determined according to the method of Troug and Meyer, 1939.

\section{RESULTS AND DISCUSSION}

Five wheat varieties (Giza 168, Sides 1, Gemmeiza 7, Gemmeiza 9 and Sakha 93) were evaluated for their susceptibility to infestation by the oat bird-cherry aphid, Rhopalosiphum padi L. during two successive seasons 2005\06 and 2006\07.

Data tabulated in Tables $(1,2,3 \& 4)$ show that the weekly counts of $R$. padi and aphid parasitoids Aphidius matricaria and Aphidius colemani and predators, Paederus alfierii, Chrysoperla carnea, Coccinella unedcimpunctata, C. septempunctata, Cydonia vicina nilotica, Cydonia vicina isis and Hippodamia variegata on wheat plants of the two seasons at Ismailia Research Station, Ismailia Governorate during 2006/07 seasons. Presence of aphids, $R$. padi on five varieties was detected throughout the whole period of plant growth from December to April during both seasons. Generally, higher abundance of $R$. padi on all wheat varieties occurred throughout the period between January up to the third week of March during both seasons. The data showed significant differences between all tested wheat varieties in their seasonal mean infestation by $R$. padi. From data in Tables (1\&2), plants of Sides 1 variety were the heaviest infested by $R$. padi showing a two seasons overall mean 39.22 individuals $\backslash 10$ plants(39.44 and 39 aphid individuals in 2005\06 and 2006\07, respectively), being the most susceptible wheat variety among the tested ones. Gemmeiza 9 came the next (seasonal means, 37.51 and 34.63 individuals, respectively with a mean of 36.07 individuals). On contrary, Sakha 
93 variety appeared as the least susceptible showing the lowest aphid numbers with a two seasons mean of 21.11 (25.13 and 17.09 individuals, respectively), being the least susceptible variety against $R$. padi infestation. Giza 168 ranked the second after Gemmeiza 9 in susceptible to aphid infestation (26.14 and 19.30 individuals\ 10 plants, in the two seasons respectively), while the $5^{\text {th }}$ variety (Gemmeiza 7) manifested intermediate position in susceptibility to $R$. padi infestation recording 29.18 individuals $\backslash 10$ plants as two seasons mean (29.15individuals in 2005106 season and 29.2 in $2006 \backslash 07$ season ,Tables, 1 \& 2). It could be generally observed from Tables (1\&2) that the higher population abundance of $R$. padi on wheat plants in Ismailia throughout the period extending from the $2 \frac{\text { nd }}{}$ week of February till the 2 nd or $3^{\text {rd }}$ week of March.

Table 1. Effect of abiotic factors on the population dynamics of the oat bird-cherry aphid, Rhopalosiphum padi/10 wheat plants on five wheat varieties during 2005-06 season at Agricultural Research Station, Ismailia Governorate.

\begin{tabular}{|c|c|c|c|c|c|c|c|c|c|}
\hline \multirow{2}{*}{$\begin{array}{l}\text { Weeks of } \\
\text { inspection }\end{array}$} & \multicolumn{5}{|c|}{ Wheat varieties } & \multicolumn{2}{|c|}{ Temp. } & \multicolumn{2}{|c|}{ R.H.\% } \\
\hline & Giza168 & Sides1 & Gemmeiza7 & Gemmeiza9 & Sakha93 & Max. & Min. & Max. & Min. \\
\hline Dec., $1^{\text {st }} 2005$ & 0.00 & 0.00 & 0.00 & 0.00 & 0.00 & 20.5 & 9.0 & 85.0 & 38.0 \\
\hline Dec., $2^{\text {nd }}$ & 0.00 & 0.00 & 0.00 & 0.00 & 0.00 & 21.0 & 12.5 & 85.0 & 39.0 \\
\hline Dec., $3^{\text {rd }}$ & 0.00 & 4.75 & 0.75 & 0.00 & 1.25 & 21.0 & 12.5 & 85.0 & 39.0 \\
\hline Dec., $4^{\text {th }}$ & 6.50 & 13.25 & 2.75 & 15.50 & 1.50 & 21.0 & 6.5 & 86.0 & 33.0 \\
\hline Jan., $1^{\text {st }}$ & 16.25 & 24.75 & 10.50 & 21.75 & 0.75 & 23.0 & 11.0 & 87.0 & 42.0 \\
\hline Jan., $2^{\text {nd }}$ & 7.50 & 32.50 & 3.50 & 6.25 & 6.50 & 20.0 & 8.5 & 85.0 & 33.0 \\
\hline Jan., $3^{\text {rd }}$ & 15.75 & 12.25 & 17.25 & 18.50 & 18.50 & 20.5 & 10.0 & 83.0 & 38.0 \\
\hline Jan., $4^{\text {th }}$ & 24.50 & 25.50 & 23.25 & 34.25 & 22.00 & 21.0 & 9.0 & 75.0 & 21.0 \\
\hline Feb., $1^{\text {st }}$ & 20.25 & 36.75 & 31.75 & 61.25 & 15.50 & 16.5 & 10.0 & 83.0 & 28.0 \\
\hline Feb., $2^{\text {nd }}$ & 38.75 & 78.50 & 50.00 & 71.50 & 25.75 & 23.0 & 5.0 & 86.0 & 16.0 \\
\hline Feb., $3^{\text {rd }}$ & 52.25 & 53.75 & 55.75 & 109.75 & 46.50 & 22.0 & 10.3 & 84.0 & 28.0 \\
\hline Feb., $4^{\text {th }}$ & 89.75 & 104.50 & 100.25 & 65.50 & 77.00 & 25.0 & 15.5 & 59.0 & 16.0 \\
\hline March., $1^{\text {st }}$ & 37.50 & 85.50 & 48.50 & 145.75 & 115.50 & 30.0 & 15.0 & 66.0 & 17.0 \\
\hline March., $2^{\text {nd }}$ & 113.25 & 123.75 & 120.25 & 76.50 & 51.75 & 25.0 & 16.5 & 86.0 & 47.0 \\
\hline March., $3^{\text {rd }}$ & 19.50 & 43.50 & 19.75 & 9.25 & 37.75 & 21.0 & 8.2 & 85.0 & 22.0 \\
\hline March., $4^{\text {th }}$ & 2.75 & 24.75 & 8.50 & 2.00 & 4.50 & 22.5 & 11.7 & 84.0 & 33.0 \\
\hline April, $1^{\text {st }}$ & 0.00 & 6.50 & 2.75 & 0.00 & 2.50 & 21.5 & 14.0 & 75.0 & 22.0 \\
\hline Total & 444.50 & 670.50 & 495.50 & 637.75 & 427.25 & - & - & - & - \\
\hline Mean & $26.14 d$ & $39.44 a$ & $29.15 c$ & $37.51 \mathrm{~b}$ & $25.13 d$ & - & - & - & - \\
\hline LSD & & & & 1.377 & & & & & \\
\hline F value & & & & 227.9 & & & & & \\
\hline
\end{tabular}

The same letter in the same row is non-significant relationship 
Table 2. Effect of abiotic factors on the population dynamics of the oat bird-cherry aphid, Rhopalosiphum padi / 10 wheat plants on five wheat varieties during 2006/07 season at Agricultural Research Station of Ismailia Governorate.

\begin{tabular}{|c|c|c|c|c|c|c|c|c|c|}
\hline \multirow{2}{*}{$\begin{array}{l}\text { Weeks of } \\
\text { inspection }\end{array}$} & \multicolumn{5}{|c|}{ Wheat varieties } & \multicolumn{2}{|c|}{ Temp. } & \multicolumn{2}{|c|}{ R.H.\% } \\
\hline & Giza168 & Sides1 & Gemeiz & Gemeiza & Sakha9 & Max & Min. & Max. & Min. \\
\hline Dec., $1^{\text {st }}$ & 0.00 & 0.00 & 0.00 & 0.00 & 0.00 & 27.0 & 13.7 & 83.0 & 18.0 \\
\hline Dec., $2^{\text {nd }}$ & 0.00 & 1.25 & 0.00 & 0.00 & 0.00 & 24.0 & 12.0 & 83.0 & 56.0 \\
\hline Dec., $3^{\text {rd }}$ & 0.50 & 0.75 & 1.75 & 0.75 & 1.50 & 20.0 & 10.0 & 83.0 & 19.0 \\
\hline Dec. $4^{\text {th }}$ & 1.50 & 2.25 & 3.50 & 2.50 & 3.75 & 17.0 & 7.5 & 84.0 & 44.0 \\
\hline Jan., $1^{\text {st }}$ & 2.75 & 10.50 & 5.75 & 4.50 & 4.50 & 22.0 & 8.8 & 84.0 & 39.0 \\
\hline Jan., $2^{\text {nd }}$ & 11.75 & 16.25 & 11.25 & 12.25 & 2.75 & 19.0 & 8.0 & 83.0 & 36.0 \\
\hline Jan., $3^{\text {rd }}$ & 20.75 & 28.75 & 31.25 & 36.75 & 11.75 & 18.5 & 7.0 & 83.0 & 37.0 \\
\hline Jan., $4^{\text {th }}$ & 13.50 & 39.50 & 24.50 & 26.00 & 20.75 & 17.0 & 5.5 & 83.0 & 42.0 \\
\hline Feb., $1^{\text {st }}$ & 26.25 & 48.25 & 45.75 & 31.75 & 25.50 & 20.3 & 6.5 & 83.0 & 36.0 \\
\hline Feb., $2^{\text {nd }}$ & 30.75 & 42.75 & 35.50 & 36.50 & 17.25 & 19.2 & 10.5 & 72.0 & 28.0 \\
\hline Feb., $3^{\text {rd }}$ & 49.50 & 57.75 & 53.75 & 65.50 & 31.00 & 16.0 & 9.0 & 83.0 & 45.0 \\
\hline Feb., $4^{\text {th }}$ & 28.25 & 91.00 & 35.25 & 49.75 & 33.50 & 20.5 & 11.0 & 82.0 & 44.0 \\
\hline March., $1^{\text {st }}$ & 36.50 & 81.50 & 47.50 & 78.25 & 49.50 & 23.5 & 10.5 & 84.0 & 35.0 \\
\hline March., $2^{\text {nd }}$ & 57.50 & 110.7 & 75.50 & 97.50 & 29.00 & 23.0 & 9.0 & 84.0 & 31.0 \\
\hline March., $3^{\text {rd }}$ & 29.25 & 125.0 & 95.25 & 115.75 & 47.50 & 30.5 & 14.0 & 81.0 & 18.0 \\
\hline March., $4^{\text {th }}$ & 16.75 & 6.50 & 25.75 & 27.50 & 12.25 & 19.0 & 11.2 & 83.0 & 43.0 \\
\hline April, $1^{\text {st }}$ & 2.75 & 0.00 & 4.00 & 3.50 & 0.00 & 21.0 & 11.0 & 83.0 & 36.0 \\
\hline Total & 328.25 & 663.0 & 496.25 & 588.25 & 290.50 & - & - & - & - \\
\hline Mean & $19.30 \mathrm{D}$ & 39.00 & $29.20 \mathrm{C}$ & $34.63 \mathrm{~B}$ & $17.09 \mathrm{E}$ & - & - & - & - \\
\hline LSD & & & & & 174 & & & & \\
\hline F value & & & & & 5.04 & & & & \\
\hline
\end{tabular}

As respect to the parasitoids \& predators known as natural enemies of aphids, those were expressed as means of total counts of larvae, nymphs and adults which were detected weekly throughout the plant growth period during both seasons 2005\06 \& 2006\07. The presence of parasitoids \&predators was detected at the periods from the third week of December till third week of March during the two successive seasons. In spite of the low weekly mean counts of natural enemies, Statistical analysis showed significant differences between all seasonal mean counts of parasitoids and predators on all tested varieties in the two seasons (Tables 3,4). By comparing the two seasons' means, plants of Sakha 93 wheat variety hardboard the highest population density of parasitoids showing 1.08 (1.06 and 1.10 individuals $\backslash 10$ plants in 2005\06 and 2006\07 wheat season, respectively), followed by Side's 1 (0.88: 0.19 and 1.57 individuals) and Giza 168 (0.83 as a two seasons mean, 0.66 and 0.99 individuals, respectively).while, on contrary, Gemmeiza 7 variety harbored the lowest population abundance of parasitoid adults $(0.61,0.37$ and 0.85 individuals), followed by Gemmeiza 9 which showed 0.21 and 1.21 individuals as means of the two season, respectively (mean 0.71) (Tables, $3 \& 4$ ).

As regard to counts of predators (different stages) counted on wheat plants, data in Tables, $(3 \& 4)$ indicated that Sides 1 variety harbored the highest population abundance of insect predators showing the two seasons mean of 1.76 (1.69 in 
$2005 \backslash 06$ and 1.82 in 2006\07) individuals $\backslash 10$ plants. That was followed by Gemmeiza7 ( 0.37 and 1.56 individuals in the two seasons resp.). On contrary, Giza 168 harbored the lowest population abundance of predators (0.49 and 0.19), Sakha $93(0.36,0.31$ and 0.40 in the two seasons resp.), and Gemmeiza 9 which harbored 0.48 individual as mean of two seasons, 0.47 and 0.49 individual, respectively (Tables, 3 \& 4).

The data in (Tables, $3 \& 4$ ) show that the period of higher abundance of parasitic and predaceous insects, which are known to survive on aphids, extended from the $2^{\text {nd }}$ or $3^{\text {rd }}$ week of January up to the $1^{\text {st }}$ or $2^{\text {nd }}$ week of March in both years. This period, actually, coincided with the period of higher abundance of $R$. padi on wheat plants (Table, 1\&2). This observation confirms that the presence of these beneficial natural enemies on wheat plants was dependent upon the presence of their natural host (or prey), i.e. aphids on these plants.

Table 3. Population dynamics of natural enemies (parasitoids and predators) associated with $R$. padil 10 wheat plants on five wheat varieties during 2005/06 season at Ismailia Agricultural Research Station.

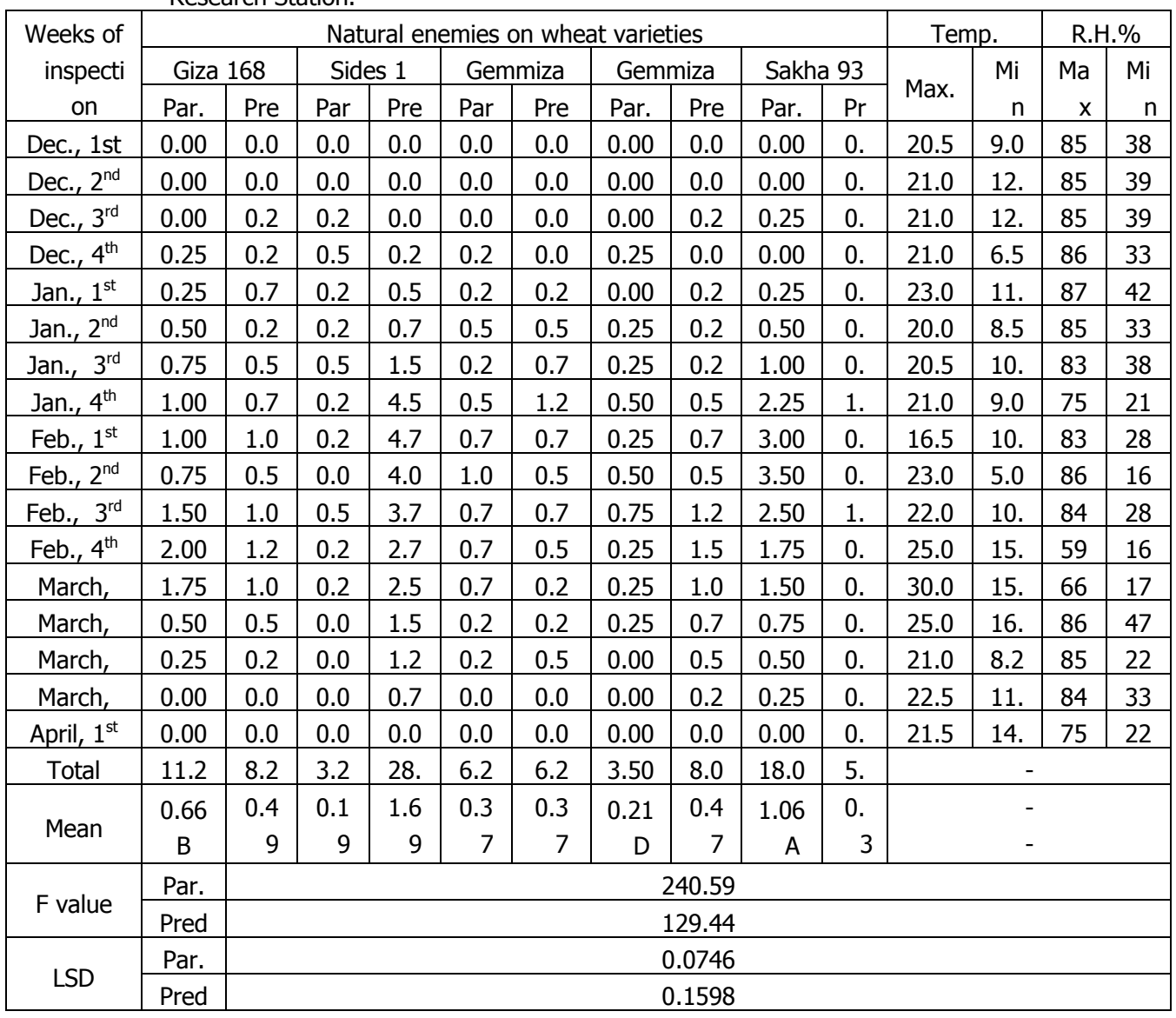

Counts followed by the same letter in the same row is non-significant relationship $*$ Par. = Parasitoids and Pred. 
Table 4. Population abundance of natural enemies (parasitoids and predators) associated with R.padil10 wheat plants on five wheat varieties during 2006/07 season at Ismailia Agricultural Research Station

\begin{tabular}{|c|c|c|c|c|c|c|c|c|c|c|c|c|c|c|}
\hline \multirow{3}{*}{$\begin{array}{l}\text { Weeks of } \\
\text { inspection }\end{array}$} & \multicolumn{10}{|c|}{ Natural enemies on wheat varieties } & \multicolumn{2}{|c|}{ Temp. } & \multicolumn{2}{|c|}{ R.H.\% } \\
\hline & \multicolumn{2}{|c|}{ Giza 168} & \multicolumn{2}{|c|}{ Sides 1} & \multicolumn{2}{|c|}{ Gemmeiza 7} & \multicolumn{2}{|c|}{ Gemmeiza 9} & \multicolumn{2}{|c|}{ Sakha 93} & \multirow{2}{*}{ Max } & \multirow{2}{*}{ Min } & \multirow{2}{*}{ Max. } & \multirow{2}{*}{ Min } \\
\hline & Par. & Pred. & Par. & Pred. & Par. & Pred. & Par. & Pred. & Par. & Pred. & & & & \\
\hline Dec., 1st 2006 & 0.00 & 0.00 & 0.00 & 0.00 & 0.00 & 0.00 & 0.00 & 0.00 & 0.00 & 0.00 & 27.0 & 13.7 & 83.0 & 18.0 \\
\hline Dec., 2nd & 0.00 & 0.00 & 0.25 & 0.25 & 0.00 & 0.00 & 0.00 & 0.00 & 0.00 & 0.00 & 24.0 & 12.0 & 83.0 & 56.0 \\
\hline Dec., 3rd & 0.00 & 0.00 & 0.25 & 0.25 & 0.25 & 0.25 & 0.00 & 0.00 & 0.25 & 0.00 & 20.0 & 10.0 & 83.0 & 19.0 \\
\hline Dec., 4th & 0.25 & 0.00 & 0.75 & 0.50 & 0.25 & 1.00 & 0.25 & 0.00 & 0.25 & 0.25 & 17.0 & 7.5 & 84.0 & 44.0 \\
\hline Jan., 1st 2007 & 0.50 & 0.50 & 1.50 & 0.75 & 0.50 & 1.25 & 0.50 & 0.00 & 0.50 & 0.00 & 22.0 & 8.8 & 84.0 & 39.0 \\
\hline Jan., 2nd & 0.25 & 0.25 & 2.75 & 1.25 & 0.75 & 1.50 & 1.00 & 0.25 & 1.00 & 0.25 & 19.0 & 8.0 & 83.0 & 36.0 \\
\hline Jan., 3rd & 1.00 & 0.25 & 3.50 & 1.50 & 1.25 & 2.25 & 1.25 & 0.25 & 1.75 & 0.50 & 18.5 & 7.0 & 83.0 & 37.0 \\
\hline Jan., 4th & 1.00 & 0.25 & 3.75 & 3.00 & 1.50 & 2.50 & 1.75 & 0.50 & 2.25 & 1.00 & 17.0 & 5.5 & 83.0 & 42.0 \\
\hline Feb., 1st & 1.50 & 0.00 & 4.00 & 4.50 & 1.00 & 2.25 & 2.00 & 1.00 & 3.00 & 1.25 & 20.3 & 6.5 & 83.0 & 36.0 \\
\hline Feb., 2nd & 2.00 & 0.25 & 2.75 & 5.50 & 1.25 & 2.00 & 2.25 & 0.75 & 1.50 & 1.00 & 19.2 & 10.5 & 72.0 & 28.0 \\
\hline Feb., 3rd & 3.00 & 0.25 & 2.257 & 4.50 & 1.00 & 2.00 & 2.00 & 1.50 & 1.75 & 0.75 & 16.0 & 9.0 & 83.0 & 45.0 \\
\hline Feb., 4th & 2.75 & 0.00 & 1.75 & 3.25 & 2.50 & 3.25 & 1.50 & 1.25 & 2.75 & 0.50 & 20.5 & 11.0 & 82.0 & 44.0 \\
\hline March, 1st & 1.75 & 0.75 & 1.50 & 2.75 & 2.00 & 3.50 & 1.00 & 1.00 & 1.75 & 0.50 & 23.5 & 10.5 & 84.0 & 35.0 \\
\hline March, 2nd & 1.25 & 0.50 & 1.00 & 2.00 & 1.75 & 2.75 & 2.75 & 0.75 & 1.00 & 0.50 & 23.0 & 9.0 & 84.0 & 31.0 \\
\hline March, 3rd & 0.75 & 0.25 & 0.50 & 0.75 & 0.25 & 1.75 & 2.00 & 0.50 & 0.75 & 0.25 & 30.5 & 14.0 & 81.0 & 18.0 \\
\hline March, 4th & 0.50 & 0.00 & 0.25 & 0.25 & 0.00 & 0.25 & 1.75 & 0.25 & 0.25 & 0.00 & 19.0 & 11.2 & 83.0 & 43.0 \\
\hline Total & 16.75 & 3.25 & 26.60 & 31.01 & 14.51 & 26.57 & 20.58 & 8.25 & 18.75 & 6.75 & - & - & - & - \\
\hline Mean & $0.99 \mathrm{~cd}$ & $0.19 \mathrm{C}$ & $1.57 \mathrm{a}$ & $1.82 \mathrm{~A}$ & $0.85 \mathrm{~d}$ & $1.56 \mathrm{~A}$ & $1.21 \mathrm{~b}$ & $0.49 \mathrm{~B}$ & $1.10 \mathrm{bc}$ & $0.40 \mathrm{BC}$ & - & - & - & - \\
\hline \multirow{2}{*}{ F value } & Par.* & \multicolumn{13}{|c|}{17.64} \\
\hline & Pred.** & \multicolumn{13}{|c|}{77.24} \\
\hline \multirow{2}{*}{ LSD } & Par. & \multicolumn{13}{|c|}{0.2061} \\
\hline & Pred. & \multicolumn{13}{|c|}{0.2661} \\
\hline
\end{tabular}


As regard to correlation coefficient between a biotic and biotic factors during 2005/06 season with the $R$. padi population these was significant positive correlation with max. temperature in all five wheat varieties during the first season (Table 5). The correlation coefficient ranged between -0.27-0.47 with max. temperature. With min. temperature, the data showed that correlation coefficient values significantly positive with the $R$. padi numbers. $\mathrm{r}$, values ranged from $0.51-0.77$. With $\mathrm{RH} \%$, the R.padi numbers, negative correlated with max. RH\% ( $r$ values) ranged between $0.11 \&-0.51$. In case of min. $\mathrm{RH} \%$, results showed the different relations with $R$. padi numbers. There was negative correlation $(r)=-0.41 \&-0.43$ in case of Sides 1 and Gemmeiza 9, respectively (Table 5), but the significantly positive correlation was showed in case of Giza 168 , Gemmiza 7 and Sakha 93. The simple correlation coefficient showed that significantly negative relationship between the $R$. padi numbers and parasitoids except in Sides 1 \& Gemmeiza 7, $r$ values were significantly positive $(0.71-0.70$, respectively). In case of predators, the significant positive correlation ranged from $0.59-0.68$ was reported with $R$. padi numbers (Table 5). Data revealed the significant positive correlation with max. \& min. temperature during the second season (Table 6). Also, the same relationship was recorded with max. RH \% during the second season but insignificant in case of Gemmeiza 9, with $\min$. RH \%. The non significant positive correlation values ranged from $0.38-0.45$, in Sides1, Gemmieza 7\& Gemmieza 9 but significant relation in case of Giza 168 \& Sakha 93 during 2006/07 season. Table (6) showed the highly significant positive relationship with both parasitoids and predators during 2006/07 season.

Table 5. Correlation coefficient values of each of a biotic and biotic factors with population abundance of Rhopalosiphum padi on five wheat varieties during 2005/2006 seasons.

\begin{tabular}{|c|c|c|c|c|c|c|c|c|c|c|c|c|}
\hline \multirow{4}{*}{ Varietys } & \multicolumn{8}{|c|}{ a biotic (weather) factors } & \multicolumn{4}{|c|}{ Biotic factors } \\
\hline & \multicolumn{4}{|c|}{ Temp. } & \multicolumn{4}{|c|}{ R.H. \% } & \multirow{2}{*}{\multicolumn{2}{|c|}{ Parasitoids }} & \multirow{2}{*}{\multicolumn{2}{|c|}{ Predators }} \\
\hline & \multicolumn{2}{|c|}{ Max. } & \multicolumn{2}{|c|}{ Min. } & \multicolumn{2}{|c|}{ Max. } & \multicolumn{2}{|c|}{ Min. } & & & & \\
\hline & $r$ & $P$ & $r$ & $\mathrm{P}$ & $r$ & $\mathrm{P}$ & $r$ & $\mathrm{P}$ & $r$ & $P$ & $r$ & $\mathrm{P}$ \\
\hline Giza 168 & 0.46 & $\mathrm{~N}$ & 0.51 & $*$ & -0.11 & $\mathrm{~N}$ & 0.36 & $*$ & -0.65 & $* *$ & 0.61 & $* *$ \\
\hline Sides 1 & 0.38 & $\mathrm{~N}$ & 0.63 & $* *$ & -0.30 & $\mathrm{~N}$ & -0.41 & $\mathrm{~N}$ & 0.71 & $* *$ & 0.59 & $* *$ \\
\hline Gemmeiza 7 & 0.47 & $\mathrm{~N}$ & 0.52 & $*$ & -0.17 & $\mathrm{~N}$ & 0.40 & $\mathrm{~N}$ & 0.70 & $* *$ & 0.65 & $* *$ \\
\hline Gemmeiza 9 & 0.27 & $\mathrm{~N}$ & 0.62 & $* *$ & -0.41 & $\mathrm{~N}$ & -0.43 & $\mathrm{~N}$ & -0.85 & $* * *$ & 0.67 & $* *$ \\
\hline Sakha 93 & 0.46 & $\mathrm{~N}$ & 0.77 & $* * *$ & -0.51 & $\mathrm{~N}$ & 0.69 & $*$ & -0.87 & $* * *$ & 0.68 & $* *$ \\
\hline
\end{tabular}

Correlation coefficient " $r$ " Probability "P" $N=$ nonsignificant 
Table 6. Correlation coefficient values of weather factors and natural enemies with population abundance of $R$. padion five wheat varieties during 2006/2007

\begin{tabular}{|c|c|c|c|c|c|c|c|c|c|c|c|c|}
\hline \multirow{4}{*}{ Varietys } & \multicolumn{8}{|c|}{ a biotic (weather) factors } & \multicolumn{4}{|c|}{ Biotic factors } \\
\hline & \multicolumn{4}{|c|}{ Temp. } & \multicolumn{4}{|c|}{ R.H. \% } & \multirow{2}{*}{\multicolumn{2}{|c|}{ Parasitoids }} & \multirow{2}{*}{\multicolumn{2}{|c|}{ Predators }} \\
\hline & \multicolumn{2}{|c|}{ Max. } & \multicolumn{2}{|c|}{ Min. } & \multicolumn{2}{|c|}{ Max. } & \multicolumn{2}{|c|}{ Min. } & & & & \\
\hline & $r$ & $\mathrm{P}$ & $r$ & $\mathrm{P}$ & $r$ & $P$ & $r$ & $\mathrm{P}$ & $r$ & $\mathrm{P}$ & $r$ & $\mathrm{P}$ \\
\hline Giza 168 & 0.78 & $* * *$ & 0.68 & $* *$ & 0.54 & $*$ & 0.66 & $* *$ & 0.81 & $* * *$ & 0.91 & $* * *$ \\
\hline Sides 1 & 0.63 & $* *$ & 0.71 & $* * *$ & 0.49 & $*$ & 0.44 & NS & 0.89 & $* * *$ & 0.76 & $* * *$ \\
\hline Gemiza 7 & 0.58 & $*$ & 0.70 & $* * *$ & 0.52 & $*$ & 0.45 & NS & 0.84 & $* * *$ & 0.65 & $* *$ \\
\hline Gemiza 9 & 0.58 & $*$ & 0.69 & $* *$ & 0.42 & NS & 0.38 & NS & 0.84 & $* * *$ & 0.68 & $* * *$ \\
\hline Sakha 93 & 0.72 & $* * *$ & 0.49 & $*$ & 0.54 & $*$ & 0.52 & $*$ & 0.81 & $* * *$ & 0.77 & $* * *$ \\
\hline
\end{tabular}

$*=$ mild significant

$* *=$ mediate significant

$* * *=$ highl significant

The infestation of aphids, $R$. padi was extensively represented in the heading stage than the seedling stage according to the representing of phytochemical components of wheat leaves. According to simple statistical analysis, the correlation coefficient between aphid numbers and nitrogen content in wheat leaves $(r)$ was positive in seedling but negative in heeding, the increase of aphid numbers with increase of nitrogen content. The correlation coefficient was 0.11 with nitrogen and aphids. While, the correlation coefficient was negative with protein, phosphorus, reduced and non-reduced sugar and potassium content, the increase of these contents decrease the aphids numbers (Table 7,8$)$

Table 7. Relationship between phytochemical components of five wheat varieties and mean numbers rates of aphids

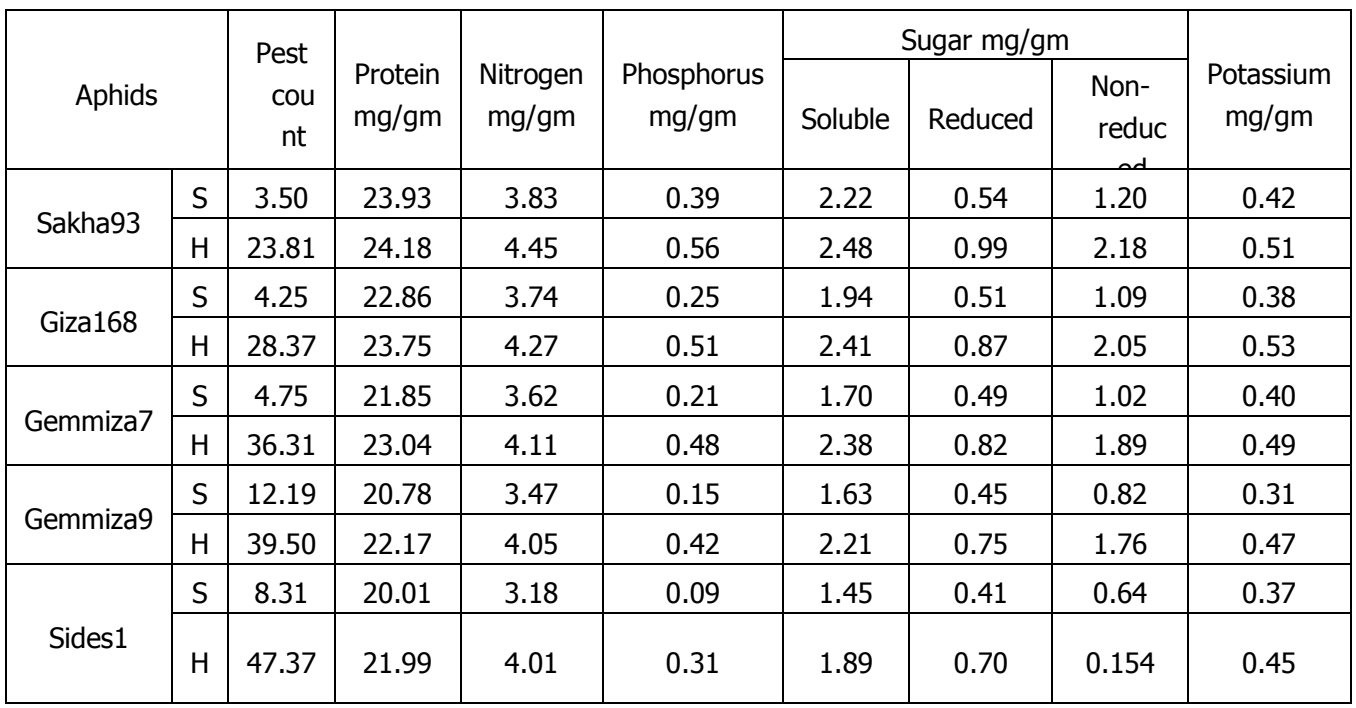


Table 8. The correlation coefficient between aphid numbers and phytochemical components of wheat leaves ( $r$ ).

\begin{tabular}{|c|c|c|c|c|c|c|c|c|}
\hline \multirow{2}{*}{\multicolumn{2}{|c|}{ Aphids }} & \multirow{2}{*}{$\begin{array}{l}\text { Protein } \\
\mathrm{mg} / \mathrm{gm}\end{array}$} & \multirow{2}{*}{$\begin{array}{l}\text { Nitrogen } \\
\text { mg/gm }\end{array}$} & \multirow{2}{*}{$\begin{array}{c}\text { Phosphorus } \\
\text { mg/gm }\end{array}$} & \multicolumn{3}{|c|}{ Sugar mg/gm } & \multirow{2}{*}{$\begin{array}{l}\text { Potassium } \\
\text { mg/gm }\end{array}$} \\
\hline & & & & & Soluble & Reduced & Non- & \\
\hline \multirow{2}{*}{ seedling } & $r$ & -0.787 & 0.108 & -0.722 & -0.691 & -0.759 & -0.767 & -0.943 \\
\hline & $\mathrm{p}$ & 0.114 & 0.862 & 0.168 & 0.1967 & 0.1364 & 0.1302 & 0.0163 \\
\hline \multirow{2}{*}{ heading } & $r$ & -0.968 & -0.950 & -0.970 & -0.924 & -0.968 & -0.855 & -0.915 \\
\hline & $\mathrm{p}$ & 0.0069 & 0.0132 & 0.0061 & 0.0249 & 0.0069 & 0.065 & 0.029 \\
\hline
\end{tabular}

Abou-Elhagag et al. (2001) evaluated the susceptibility of ten wheat varieties to cereal aphids (Rhopalosiphum padi, Schizaphis graminum and $R$. maidis) infestation in Egypt. Sides 9, Sides 7, Sides 5 and Gemmeiza 1 showed the lowest population of $R$. padi and $R$. maidis, while Sides 5, Sides 7 and Sides 9 were the least preferred varieties by S. graminum. Sides 9 , Sides 7 and Sides 5, aside from obtaining the highest yields, were the least susceptible to infestation by all cereal aphids studied. The potential impact of future climate projections on $R$. padi population dynamics, persistence, abundance, dispersal and migration events as well as the interactions between vector, virus, crop and environment have reviewed by Finlay and Luck (2011). Aphids, in particular, are likely to readily respond to climate change given their short generation times, low developmental threshold temperatures and efficient dispersal capabilities (Harrington et al., 2007). The relation abundance in $R$. padi population in sexual and asexual lineages is determined by climate, with asexual populations prevalent where winters are mild (Gilabert et al., 2009). For apterous $R$. padi mean relative growth rate measured for a range of temperatures on cereals and grasses was found to correlate positively with fecundity (Leather and Dixon, 1984). Aphids specific predators (Coccinellidae, Syripidae, Chrysopidae, Neuroptera, Itonidae, Anthocoridae, Miridae) may be important later in the season by reducing numbers of aphids (Wellings, 1991). The presence of Aphidius rhopalosiphi (parasitoid) parasitizing $R$. padi resulted in fewer plants infected with BYDV was reported by Smyrinioudis et al., 2001a. On the other hand, levels of free amino acids were decreased in leaves attacked by $R$, padi (Hubert Sytykiewicz et al., 2011). The distribution of aphids on the host plant is largely determined by difference in the quantitative-qualitative composition of phloem sap (the same previously author). The quantity and proportion between 
these nitrogen compounds in consumed food are main factors for aphids' nondisturbed growth and development (Douglas, 2006). Finally, these studies add other pieces of evidence that climatic, predators, parasitoids and the changes in levels of phytochemical component in wheat leaves may perform important role in the $R$. padi dynamics on the wheat varieties in Egypt.

\section{REFERENCES}

1. Abou-Elhagag, G. H., A. M. A. Salman and M. H. Motowe. 2001. Susceptibility of some wheat varieties to cereal aphids infestation under field conditions in Upper Egypt, Assiut Journal of Agricultural sciences, 32 (4): 29-37.

2. Akhtar, N., M.B. Anwar, G. Jilani, H.I. Javed, Yasmin, S. and I. Begum. 2008. Resistance to foliage feeding aphid in wheat. Pakistan Journal of Biological Sciences, 11(5): 801-804.

3. Akhtar, N., R.T. Hashmat, G. Jilani, S. R. Chughtai, H. Ehsan, M. Irshad, M. Ata and Yasmin, S. 2007. Resistance of different wheat lines to Rhopalosiphum padi (L.) (Aphididae: Homoptera) in Pakistan. Pakistan Journal of Zoology, 39(3): 191194.

4. Douglas, A.E. 2006. Phloem-sap feeding by animals: problems and solutions. J. Exp. Bot. 57: 747-754.

5. Finlay, K.J. and J.E. Luck. 2011. Response of the bird cherry-oat aphid (Rhopalosiphum padl) to climate change in relation to its pest status, vectoring potential and function in a crop vector virus pathosystem. Agriculture, Ecosystems and Environment, 144 : 405-421.

6. Forsee, W.T. 1938. Determination of sugar in plant material a photocolometeric method. Inds. Eng. Chem. Annal. 10 $0^{\text {th }}$ ed: 411-418.

7. Gilabert, A., J. Simon, L. Mieuzet, F. Halkett, S. Stoeckel, M. Plantegenest and C. Dedryver. 2009. Climate and agricultural context shape reproductive mode variation in an aphid crop pest. Mol. Ecol., 18: 3050-3061.

8. Harrington, R., S. Clark, S. Welham, P. Verrier, C. Denholm, M. Hulle, D. Maurice, M. Rounsevell and N. Cocu. 2007. Environmental change and the phenology of European aphids. Global Change Biol., 13: 1550-1564.

9. Havlickova, H. 1996. Differences in winter wheat varietys in aphid infestation in relationship to biochemical characteristics. Rostlinna Vyroba 42(1): 41-45.

10. Hubert, S., G. Sylwia and C. Grzegorz. 2011. Effect of the bird cherry-oat aphid, Rhopalosiphum padi $L$. feeding on phytochemical responses within the bird cherry Prunus padus L. Polish Journal Of Ecology, 59(2): 329-338

11. Leather, S. and A. Dixon. 1984. Aphid growth and reproductive rates. Entomol. Exp. Appl., 35: 137-140. 
12. Michel, K.A., J.K. Gilles, P.A. Hamilton and F. Smith. 1956. Colorimetric method for determination of sugars and related substances. Analytical Chemistry, 28 (3): 302-307.

13. Pregl, F. 1945. Quantitative organic microanalysis. 4th ed. J. and A. Chundril London, 94-101.

14. Ruchira Tiwari, V.K. Sharma and R. Tiwari. 2002. Relative susceptibility of wheat germplasms to aphids. Indian Journal of Entomology, 64(3): 324-329.

15. Sekhar, S.M.V. and V.S. Singh. 1999. Spatial distribution pattern of aphids infesting wheat. Indian Journal of Entomology, 61(4): 396-400.

16. Smyrinioudis, I., R. Harrington, S. Clark and N. Katis. 2001. The effect of natural enemies on the spread of barley yellow dwarf virus (BYDV) by Rhopalosiphum padi (Hemiptera: Aphididae). Bull. Entomol. Res., 91: 301-306.

17. Tantawi, A. H., A. H. Etman and M. A. Eglal. 1986. Aphid species on wheat plants in Egypt. Changes in their relative abundance and correlation of their initial and maximum infestation with the state of plant growth. J. Agric. Res., Tanta Univ., 12 (2): 549-565.

18. Troug, E. and A.H. Meyer. 1939. Improvement in deiness colorimetric for phosphorous and arsenic. Ind. Eng. Chem. Ann. Ed., 1: 136 - 139.

19. Webster, J.A. and D.R. Porter. 2000. Plant resistance components of two greenbug (Homoptera: Aphididae) resistant wheats. Journal of Economic Entomology, 93(3): 1000-1004.

20. Wellings, P.W. 1991. Biological control of aphids through disruption of migration. Behaviour and Impact of Aphidophaga, SPB Academic Publ., The Hague, The Netherlands, 79-83 pp. 


\section{أستجابة من الثوفان Rhopalosiphum padi L. لبعض العوامل الحيوية والغير حيوية و المحتوى الكيميائى لخمسة أصناف من القمح

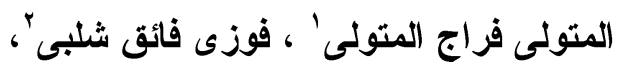

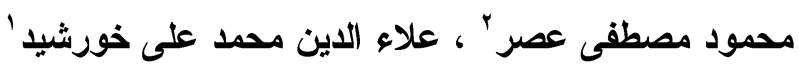 \\ معهز بحوث وقاية النباتات - مركز البحوث الزرراعية - الدقي - جيزة - مصر

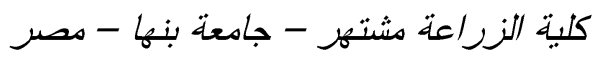

فى هذة الدراسة نم دراسة مستوى الاصعابة بمن الثوفان R. padi. L على خمس أصناف من

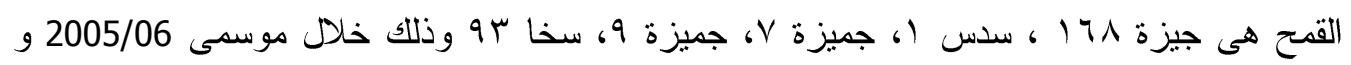

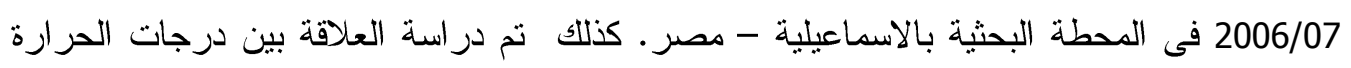
العظمى و الصغرى و الرطوبة النسبية العظمى و الصغرى و درجة تاثير هما على الكثافة العددية

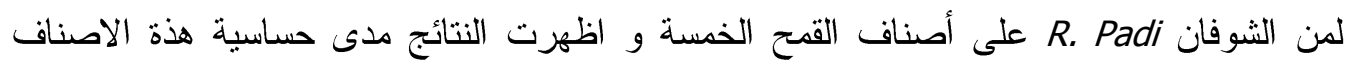

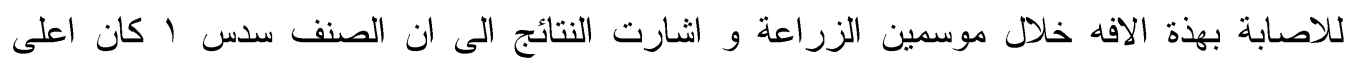

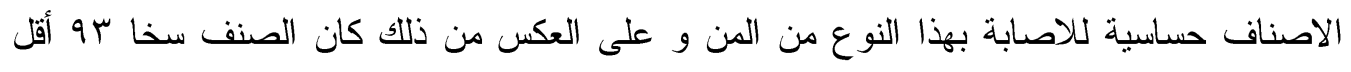

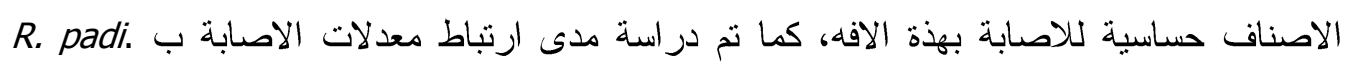
بالمحتوى الكيمائى للاور اق لكل اصناف القمح المختبرة. 